\title{
AN ANALYSIS OF RAINFALL EXTREMES IN THE NORTHERN SOUTH AMERICA AND THEIR BEHAVIORS FOR FUTURE CLIMATE BASED ON A1B SCENARIO
}

FONSECA, Paula - pamorellifonseca@gmail.com

Instituto Nacional de Pesquisas da Amazônia / INPA

VEIGA, José Augusto - veiga.uea@gmail.com

Universidade do Estado do Amazonas/ UEA

CORREIA, Francis Wagner - francis.wagner70@gmail.com

Universidade do Estado do Amazonas/ UEA

CHAN, Chou - chou.sinchan@gmail.com

Instituto Nacional de Pesquisas Espaciais/ INPE

LYRA, André - andrelyra1@gmail.com

Instituto Nacional de Pesquisas Espaciais/ INPE

\begin{abstract}
The Brazilian Amazon (BAMZ) and Northeast Brazil (NEB) regions have been facing intense climate extremes since the beginning of 21 st century. In BAMZ, these climate extremes can modify the Amazon forest and its essential role in the local and remote climate. This study evaluated whether the extreme rainfall events in the both regions will be more intense and frequent in the future due to the increase of greenhouse gas emissions. An adapted version of the RX5day index was applied to distinguish between different types of extreme rainfall cases in the ETA model output for the decade 2089-2099 compared to the 1980-1990 decade. The results have shown that although the total rainfall is expected to be reduced by at least $1 / 3$ (DJF) in the case of rare events, this kind of extreme rainfall will contribute with a higher amount of rainfall and will occur more frequently in both areas by the end of the 21st century. Heavy and very heavy events decrease for both areas (total rainfall amount and frequency). Results suggest that stakeholders must be prepared to cope with the population's need for assistance during floods and rainfall reduction and reinforces the need to adapt to worse climate extremes projections
\end{abstract}

Keywords: Extreme rainfal events, Amazon, Brazilian Northeast, Climate Change, ETA model.

ANÁLISE DOS EXTREMOS DE CHUVAS NO NORTE DA AMÉRICA DO SUL E SEUS EFEITOS NO CLIMA FUTURO COM BASE NO CENÁRIO A1B

RESUMO: A Amazônia brasileira (BAMZ) e a região nordeste (NEB) têm passado por eventos climáticos extremos desde o inicio do século XXI. Na AMZ esses extremos climáticos comprometem a floresta amazônica e seu papel essencial para o clima local e não local. Esse estudo analisou se os eventos extremos de chuva em ambas as regiões serão mais intensos e frequentes no futuro devido ao aumento dos gases do efeito estufa. Uma versão adaptada do índice RX5day foi utilizada para distinguir entre os diferentes tipos de casos de eventos extremos para os resultados das simulações numéricas, provenientes das simulações com o modelo ETA para a década de 2089-2099 e comparada a década de 1980-1990. Os resultados mostram que embora se espere uma redução $1 / 3$ no total de chuva (DJF) os eventos do tipo raro irão contribuir com uma quantidade de chuva maior e ocorrerão com mais frequência nas duas áreas no final do século XXI. Eventos forte e muito forte diminuirão nas duas áreas (total de chuva e frequência). Os resultados sugerem que os tomadores de decisão deverão estar 
preparados para lidar com a necessidade de assistência da população durante as enchentes e redução de chuvas e reforça a necessidade de adaptação para projeções de eventos climáticos piores.

Keywords: Chuva extrema, Amazônia, Nordeste Brasileiro, Mudanças Climáticas, Modelo ETA.

\section{INTRODUCTION}

Brazil has faced two major extreme climate events in this decade, namely the flood in Amazon and the drought in the Northeast region, both considered record events in the last 50 years (MARENGO et al., 2013a). These events happened in the first half of 2012, fairly close together. According to Marengo et al. (2013a) and Espinoza et al. (2013), however, the events were attributed to different dynamical phenomena. Furthermore, these extreme climate conditions have subjected the inhabitants of the Amazon and Northeast regions to great economic losses (TOMPKINS et al., 2009; HASTENRATH, 2012; MARENGO et al., 2013b; MARENGO AND BERNASCONI, 2015; MARENGO et al., 2016). Over the past half-century, the Amazon basin has experienced severe droughts and floods more frequently than normal, which has been confirmed by river level measurements (GLOOR et al., 2013; SATYAMURTY et al., 2013). The northeast region has been through the worst drought in decades (2012-until now; MARENGO et al., 2016). These are important and strong argument to justify the climate change discussion and to introduce the global warming implications to climate and weather extremes seen in this region.

The threat that global warming imposes upon the Amazon basin and the tropical forest is of great concern. Analysis by Gloor et al. (2013) has suggested an increased trend in river discharges in the Northwest Amazon over the 19902009 period combined with an increase in annual precipitation over the area. Guimberteau et al. (2013) also highlight that during 1980-2000 period, the Amazon hydrology has been severely affected by extreme climate events. Espinoza et al. (2013) examined the 2012 flood and showed that it was caused by the coincident peak of the 2 northward tributaries of the Amazon River reaching their maximum discharge in April 2012 (see also GLOOR et al., 2013). As with previous floods (1986, 1993 and 1999), the 2012 event was attributed to a La Niña episode.

As part of the climate variability in Brazilian northeast region, drought are much more frequent due to the characteristic semi-arid / arid climate which is predominant in that area (annual rainfall can vary from $2000 \mathrm{~mm}$ to $700 \mathrm{~mm}$ from the cost to the western of the region (HASTENRATH, 2012; MARENGO AND BERNASCONI, 2015), neighboring the east of AMZ region). Exacerbated use of the natural resources, soil degradation and a decrease in the total amount of rainfall over the years are some of the factors that enhance the already high probability of extensive droughts in the region (MARENGO AND BERNASCONI, 2015; MARENGO et al., 2016).

Economic losses due to recurring droughts and floods are brought to attention in Marengo et al. (2013b) for BAMZ. Citing numbers for Acre and Amazonas they showed how mistakes in investments have made the low-income population poorer. The national government facilitates substantial help and amounts of financial resources during the hazards, but this ceases after a couple 
of weeks and is not part of an effective action plan toward adaptation to climate change (MARENGO et al., 2013b). Tompkins et al. (2009) discuss the policy implemented and the challenges that lie ahead in taking steps toward better dealing with vulnerabilities in the Northeast region. On the other hand, Marengo et al (2013a; 2016) and Marengo and Bernaconi (2015) outline that since 1970's the number of human deaths caused by the drought in the NEB were drastically reduced as a consequence of the intervention made by the government over the years. The constructions of dams, government programs to offer financial help to farms that have lost crops and livestock are a few examples given by the authors (also HASTENRATH, 2012). More recently the partially conclusion of the São Francisco River water transfer system (DUARTE, 2014; MENDES et al., 2015.) is another example of the efforts to build resilience in the region, although it hasn't solve the problem yet.

Brazil experienced an unprecedented hydroelectric and water supply crisis in its Southeast region, caused by a strong reduction in precipitation in 2014-2016 (COELHO et al., 2016a,b; MARENGO AND ALVES, 2016; and NOBRE et al., 2016). Changes in the atmospheric large scale circulation, which involved the Pacific and the Atlantic oceans, implicated in an atmospheric blocking preventing the humidity coming from Amazon to enter the southeastern region (see previous references). Moreover, there was a weak South Atlantic Convergence Zone (SACZ) acting during the austral summer in the region (COELHO et. al, 2016a). Back in 2001, an energy crisis took place directly linked to a long dry period, which is mentioned in Silva et al. (2007), Marengo et al. (2012), Coelho et al. (2016a) and reported in detail by De Moraes Drumond and Ambrizzi (2005). An improved precipitation data series can help both past and future analysis of this variable behavior in South America (SILVA et al., 2007). Efforts have been made to provide model projections which could help stakeholders foresee some of the impacts that changes in extremes could cause in the future. Marengo et al. (2012) showed that the total annual rainfall in Amazonia and São Francisco Basins will decrease during the period of 20712100. Valverde and Marengo (2014) have found an increase in short-term precipitation intensity in the southeast and northern areas of the Amazon basin. When the indexes obtained from the data model were compared with those obtained from CPC data, it became clear that there might be more intense and frequent extreme rainfall events in future.

An increase in seasonal mean precipitation in large areas of the Amazon basin was observed in experiments performed with the Rossby Centre Regional Model under the A1B scenario (SORRENSSON et al., 2010). As a consequence, this could also cause an increased risk of extreme precipitation in the northern Amazon region during the austral summer. In these experiments, projections obtained for 2080-2099 were compared against simulations for 1980-1999, showing the great importance of these kinds of simulations to learn more about the behavior of extreme events. On the other hand, Guimberteau et al. (2013) performed hydrologic simulations with data from emission scenarios B1, A1B and $A 2$ to obtain discharge projections for the middle and the end of the 21st century. While in the western portion of the Amazon basin an increase in precipitation was found, which would lead to an increase in the high flow, the eastern, southern and northern areas of the basin should go through a sensitive reduction in the usually low flow (dry period, decrease of approx. 55\% in Xingu basin). 
Based on data from the PRECIS regional climate model system, Marengo et al. (2009) suggest that precipitation extremes over the north and southwestern areas of Amazonia will intensify, which will imply a greater risk of floods in the future. For eastern amazon and northeast region authors found a negative tendency for rainfall indexes calculated over 2071-2100 time slice. Blázquez et al. (2012) testing two different spatial resolutions and data from the Japanese MRI model, also found an increase in precipitation and temperature for the Amazon in the 2015-2039 and 2075-2099 time slices. For northeast region authors found negative bias of $1.0 \mathrm{~mm} /$ day.

As can be observed, results from climate projections suggesting the future of extreme events in Brazil and South America indicate clear evidence that the climate is already undergoing significant changes. However, Satyamurty et al. (2010) analyzing observed data from 18 meteorological stations, showed that only $1 / 3$ of these stations had trends indicating increase or decrease in the total annual rainfall for Amazonia.

In this paper, we aim to quantify and evaluate the future change of rainfall extremes over Brazil, focusing mainly on the Brazilian Amazon basin (BAMZ) and the Northeast region of Brazil (NEB), both which are highly vulnerable to the extreme events, especially those related to rainfall. This will be achieved by an analysis of model output data relative to a numerical experiment considering a rapid greenhouse gas emission, as proposed by the A1B scenario (NAKICENOVIC et al., 2000).

\section{MATERIAL AND METHODS}

\subsection{OBSERVED DATA}

Silva et al. (2007) presented an improved gridded precipitation based on observed data for South America, which was supposed to be used for climate and hydrologic studies as well as for large-scale anomalies analysis and, as performed here, for the evaluation of climate models. A characteristic highlighted in the previous work is the fact that the CPC dataset has fewer dry days, extreme precipitation events and a greater number of low precipitation days. These details were expected since the interpolation performs a smoothening of the variable. The daily precipitation values consist of an average value for a $0.5^{\circ}$ lat/lon spatial resolution area. These data were compared to the climate projections to indicate the proxy value of both datasets - in other words, how well the model simulates the present climate.

\subsection{NUMERICAL EXPERIMENTS}

Chou et al. (2012) described the numerical experiments performed with the limited area ETA model (MESSINGER, 1988; BLACK, 1994) to obtain 4 sets of data relative to the present climate and that of the 21 st century. The ETA model was forced by initial and boundary conditions supplied by the UK Met Office Hadley Centre (MOHC) HadCM3 global model (GORDON et al., 2000; COLLINS, et al., 2001). The global model had a $2.5^{\circ} \times 3.75^{\circ}$ lat/lon horizontal resolution with 19 vertical levels. Through a perturbed physical ensemble which involved more than 300 members, 16 different model configurations were evaluated to choose the best representation of the results range. The HadCM3 
model simulation with these different configurations used the A1B IPCC (Intergovernmental Panel on Climate Change) scenario (NAKICENOVIC et al., 2000). Finally, 3 members were selected as the best representatives for sensitivity of the global mean temperature identified as low, medium and high, beyond the unperturbed member that was obtained using the standard configuration of the HadCM3 model.

To apply the extreme rainfall identification and classification methodology, two decades were extracted from the numerical experiments results: the 1980-1990 decade, to represent the control experiment, and the 2089-2099 decade from the high sensitivity dataset, to analyze future changes of precipitation extremes. Although the model domain covers major parts of South America, our focus is on BAMZ and NEB, as illustrated in Figure 1. The choice to include only 20 years as a time slice for analysis was based in the time and computational available resources.

\subsection{IDENTIFYING AND CLASSIFYING THE RAINFALL EXTREMES}

The methodology applied to identify and classify the extreme events is based on the RX5day climate extreme index (FRICH et al., 2002; GAO et al., 2006; KLEIN TANK et al., 2009). However, to quantify and select extreme rainfall events by intensity, the adaptation proposed by Brito et al. (2014) was applied. Considering our data set, composed of 2 different decades, 1980-1990 and 2089-2099, the December-January-February trimester of each year (10 trimesters per decade) was analyzed. Thus, for the present day climate, 10 austral summers were analyzed, accounting for 900 days per decade. With these two sets isolated, we classified the extreme rainfall event based on an average obtained from a set composed of the maximum daily rainfall value in a 5 -day period, namely the climatology of the maximum rainfall. A second step was to compare each dataset value against the climatology of the maximum rainfall, and once the value was equal or higher than the climatology maximum value, it was defined as an extreme event.

The last step consisted of applying the rules to classify the rainfall precipitation events. Therefore, the events between the maximum climatology and its standard deviation were classified as heavy events. Those events higher than the climatology plus its standard deviation, and smaller than the climatology plus twice its standard deviation, were classified as very heavy events. The last category was that of rare events, in which the events were higher than the climatology plus twice its standard deviation. These procedures were performed for each grid point and for each of the time slices evaluated, thus avoiding the use of a unique threshold value over a large domain where climatology patterns can differ.

\section{RESULTS AND DISCUSSIONS}

\subsection{SPATIAL ANALYSIS}

For the purpose of comparison, the dataset from the ETA model was degraded from a $0.4^{\circ}$ lat/lon grid to a $0.5^{\circ}$ lat/lon grid to agree in spatial resolution with the CPC data. Next, the bias between ETA and CPC data for the austral summer (DJF) of the 1980-1990 decade was obtained and the results 
displayed in Figure 2. The bias for the accumulated rainfall produced by heavy events is presented in Figure $2 a$. It can be observed that for a large continent extension the model underestimates the rainfall related to heavy events, except over the areas north-northeast and south-southeast of Brazil and over the Andean regions as well. Negative values are observed over most of the Amazon region. In Figure $2 b$, we can see that the areas previously highlighted with positive differences are broader in the bias for very heavy events (Figure 2b), in the south-southeast region of Brazil. A band of positive bias is also shown and crosses from northwest to southeast in Figure 2c, which resembles the position of the SACZ. Futhermore, the expansion of the positive bias areas is differentiable between the north, south, and southeast areas of the continent, where these last two present a positive bias for accumulated rainfall ranging from 60 to $150 \mathrm{~mm}$ (Figure 2c).

The bias for Figure 3 were obtained by subtracting the future climate represented by the 2089-2099 decade - from the current climate, represented by the 1980-1990. The Figures 3a, 3b, and 3c are specific for the bias of heavy, very heavy and rare events respectively. Negative biases for most of the Brazilian extension are found for heavy and very heavy extreme events, including the BAMZ and NEB (Figures $3 a$ and $3 b$ ). However, in Figure $3 b$, it is discernible that areas with positive bias are expanding northward in both regions even though the range does not vary in the same intervals (anomalies between 10-200 $\mathrm{mm}$ in Fig. 3a and between 5-120 mm in Fig. 3b). Rare events, for which the biases are shown in Figure $3 c$ presents a major extension with positive values for both BAMZ and NEB regions. Amazonas State presents practically its whole extension with a positive bias $(\sim 60 \mathrm{~mm})$. Pará, Maranhão and Acre State present approximately half of their extensions with similar values. These results partially agree with the increased tendency obtained from Brito et al. (2014), which observed the highest values for 1998-2013 in northern Pará and Southern Amazonas State, indicating that the observed patterns should continue in the future. Negative biases of less than $1 \mathrm{~mm} /$ day were found for NEB in 2071-2100 time-slice (MARENGO AND BERNASCONI, 2015) using CMIP3 HadCM3 data, downscaled by ETA model (CHOU et al., 2012). Decrease in precipitation for NEB were also found in Marengo et al. (2009) between 10$15 \%$ (B2), and for the A2 scenario, could be up to $40 \%$ drier in the 2071-2100 time-slices. Marengo et al. (2016) discussing the CMIP5 projections for NEB, downscaled by ETA model simulations, for the 4 RCP (Representative Concentration Pathways, 2.6,4.5,6.0,8.5) found a broader area with positive bias, the higher the RCP, the broader the area in the north (Maranhão, north of Piauí, Ceará and Rio Grande do Norte) of the northeast region with biases $\geq$ $0.5 \mathrm{~mm} /$ day. As can be observed, depending on the different projections used (CMIP3 and CMIP5) you may have different results for NEB, and the most recent ones points out to a not so dry future for the previous months of the peak of the rainy season, depending on the RCP considered.

In Colombia, Venezuela and Peru a similar spatial pattern is noticed when the bias obtained for heavy, very heavy and rare events show changes from negative to positive, indicating a higher precipitation quantity associated with this type of event also for these countries.

The Roraima State, one of the areas highlighted by Brito et al. (2014), presents a decrease in the accumulated rainfall for heavy and very heavy events, agreeing with the behavior evaluated by the authors. This pattern was 
also observed for coastal areas (east to west, north of the continent). The bias also increases from negative to positive in the southwestern Amazon and southeastern Brazil regions, which resembles the climatological position of the $S A C Z$, as can be seen from Figures 3a-c.

Another parameter calculated in this work was the percentage contribution of each type of extreme event to the total amount of rainfall precipitated over the continent. Figures $3 d$, $3 e$ and $3 f$ present the bias between these percentages, obtained by subtracting the future from the present climate. Northeast Amazon presents a positive bias located in Pará State, ranging from $10-30 \%$ in Figure $3 \mathrm{~d}$ and $15-20 \%$ in Figure 3e. Heavy events contribution in northwestern Amazonas State varies from 10-20\% (Figure 3d), and from 10$15 \%$ for very heavy events (Figure $3 e$ ). These positive values indicate that these two particular types of extreme events will account for a higher amount of precipitation in the future (compared to the total precipitation in the area).

For rare events the Figure $3 c$ shows that most Brazilian territory presents a positive bias, indicating that this type of extreme event will be responsible for a major amount of rainfall in the final decade of the 21 st century when compared to the reference decade. The contribution from rare events presents an increase in NEB ranging from 5 to $50 \%$, which means that this kind of extreme event will be responsible for a higher amount of the total precipitation in this area for the DJF trimester. West-central Brazil, southwestern BAMZ, neighboring countries and most of the rest of the continent present values ranging from 5 to $10 \%$, suggesting that these areas will have fewer changes with regard to the amount of precipitation attributed to rare events (Figure 3f).

Chou et al. (2014) performed climate simulation using HadGEM2-ES (COLLINS et al., 2011; MARTIN et al., 2011), which replaced the previous version HadCM3 used in their previous work (CHOU et al., 2012; MARENGO et al., 2012), and also as a base for the present study. The authors discern an area covering the north region of Brazil with a decreased precipitation (DJF) but it seems to be moving towards south of Brazil when the results from the former simulations are compared to the newest ones.

Bellprat et al. (2015) performed an analysis also using HADGEM2-ES projections. Even with all the improvements made from the older version (HadCM3) to the new one (HADGEM2-ES) the authors concluded that precipitation variability in the South America is still poorly represented which prevents any robust affirmation regarding seasonal rainfall extremes. It suggests that it is necessary to continue employing efforts to improve the representation of convective process, for example, which happens in sub-grid scales.

Chadwick et al. (2015) also used CMIP5 datasets. It is suggested that to advance in public policies and planning, it is necessary to know what kind of extreme event will be more probable, the area where it is supposed to happen, and an estimation of its magnitude. The study also analyzed the use of ensembles explaining that it masks important results, as an agreement of the areas prone to reduction in rainfall.

Comparing our results, obtained using the scenario A1B from IPCC (2007) to the ones obtained by more recent studies, using the RCP's (CMIP5), for example, Chadwick et al. (2015) indicate that north of Amazon and NEB as 
well the area where there is a transition from Amazon to the semi-arid are expected to go through a reduction in precipitation, during the 2071-2100 period compared to 1971-2000. The study estimates changes around $\pm 20 \%$ in precipitation in approximately $25 \%$ of the tropical area affected (Brazil has $13 \%$ of this area) under the RCP 8.5. All these findings agree with the results found in our analysis. Marengo et al. (2016) analyzing precipitation changes under the RCP 8.5 highlight a positive bias in the north area of the NEB, which includes Maranhão, north of Piaui, Ceará and most of Rio Grande do Norte state. Smaller positive values are found for semi-arid region and neutral values are associated to east coast of Brazil. These results were obtained for the DJF trimester. Considering conclusions pointed out by Hastenrath (2012) regarding the importance of the precipitation in the months previous to the peak of the rainy season in the NEB region associated with a favorable SST gradient in the Tropical South Atlantic and in the Tropical Eastern Pacific oceans, it may be a positive feature for the end of the century.

\subsection{INTEGRATED ANALYSIS}

To better assess the changes regarding extreme precipitation events, the results were integrated in the target areas. The first set of graphics shows the average rainfall in the region attributed to each type of rainfall extreme. Figure $4 a$ presents the total rainfall averaged for heavy events, for the 10 trimesters in each decade in the BAMZ. A decrease from $142 \mathrm{~mm}$ to $100 \mathrm{~mm}$ is observed, which represents almost $30 \%$ less rainfall in the area. In the secondary axis, the accumulated events are plotted to show the average for the 10 trimesters in each decade. This parameter has decreased too, representing almost $13 \%$ fewer events in the future. For very heavy events, presented in Figure 4b, there are also decreases by $\sim 30 \%$ for accumulated rainfall and by $20 \%$ for events in this category. For rare events, a slight increase for accumulated rainfall of $2 \mathrm{~mm}$ on average is observed, accounting for $4 \%$ more rainfall when compared to the 1980-1990 decade (Figure 4c). Accumulated events show an increase of nearly $4 \%$, which corresponds to 105 more events by the end of the 21st century.

Figure $4 d$ presents the bias in percentage of rainfall produced by each type of event; according to this figure, it is observed that all types of events decrease over BAMZ except the rare events. This was expected considering the charts already shown (for average rainfall).

Using the RCP 8.5, according to Chadwick et al. (2015), changes in the precipitation amount no longer associated to the expected climate variability are already present by the middle of this century, which is much sooner than expected. Chen et al. (2014) analyzed a not so extreme RCP (4.5) and concluded that there is greater certainty for areas that will be dryer than the ones that will be wetter. They also used the R5day index for the 2080-2099 time-slices and compared with the 1986-2005 period. Authors concluded in Amazon basin there is a consensus between models that there will be reduction in the precipitation during all seasons, which also agrees with our results.

Frequency results presented in Figure $4 \mathrm{e}$ show increases in normal rainfall and rare events ( $2 \%$ and $5 \%$ respectively), while heavy and very heavy events present decreases of $13 \%$ and $19 \%$ respectively. In terms of contributions of each type of extreme event to the total rainfall, normal rainfall 
decreases by $8 \%$ while all other types of extreme rainfall increase. The sum of all extreme events and rare events present nearly $5 \%$ and $4 \%$ more rainfall respectively, while heavy and very heavy events increased by less than $1 \%$.

The parameters of the NEB are reported in Figure 5. The accumulated rainfall decreased from $108 \mathrm{~mm}$ to $64 \mathrm{~mm}$, which represents a decrease of about $40 \%$ in heavy events on average (Figure $5 \mathrm{a}$ ). Comparing the accumulated events for both decades, there is a decrease of 25\% in the 2089-2099 decade. For very heavy events (Figure 5b), the same decrease tendency is shown, by 19 $\mathrm{mm}$ and 435 events, $\sim 33 \%$ and $\sim 25 \%$ less rainfall and frequency, respectively. Still, rare events presents an increase of $4 \mathrm{~mm}$ which accounts for $10 \%$ more precipitation and an extra 54 events on average, accounting for $6 \%$ more events in the future (Figure 5c). It is important to highlight that the trimester analyzed do not correspond to the peak of the rainy season in the region, which according to authors previously cited goes from February-May.

In the second row, Figures $5 \mathrm{~d}-\mathrm{f}$ reports the differences in percentage between the following analyzed parameters. From figure $5 d$, a decrease of $39 \%$ can be observed in the total amount of rainfall, and consequently a decrease in the amounts of heavy and very heavy events, of $40 \%$ and $32 \%$ respectively. Only rare events are increased, by nearly $12 \%$ (Figure $5 \mathrm{~d}$ ).

Besides this parameter, the frequency of normal and rare events will increase in the Northeast region by $3 \%$ and $7 \%$ respectively, as can be observed in Figure $5 \mathrm{e}$. In the same figure, heavy and very heavy events will reduce by $26 \%$ and $24 \%$ respectively in their frequencies. A decrease can also be seen in normal and heavy events' contribution to the total rainfall (Figure 5f), although the latter is less than $1 \%$. The sum of all extreme events, very heavy and rare events present an increase which varies from $2 \%$ (very heavy events) to $12 \%$ (all types of extreme events).

Summarizing our findings, Table 1 presents the results obtained throughout the analysis. The total rainfall averages associated with the heavy and very heavy events are reduced, although an increase was observed for rare events in both studied areas, as can be seen from arrows pointing down and up. Average frequency agrees with average rainfall, in terms both of increase and of decreasing signs for the three types of events in these two areas. Average frequency is shown in graphics $4 a-c$ and $5 a-c$ (lines laying over bars), and the bias calculated from the absolute frequency values is shown in figures $4 \mathrm{e}$ and $5 \mathrm{e}$ for both areas. Total rainfall attributed to each kind of event also agrees with the previous parameters (i.e., increases and decreases found for the same types of events; Figures $4 d-5 d$ ). The contribution to the total rainfall, however, presents a difference between the two areas only for heavy events (it increases, like all the other types of rainfall events), but in the Northeast region it decreases, while the other parameters increase, agreeing with the Amazon numbers.

Comparing both regions, it is possible to observe similarities in the measured parameters. For heavy and very heavy events, both areas present a decrease in the total average rainfall and frequency for the DJF trimester in 2089-2099 (Figures 4a, 4b and 5a, 5b). On the other hand, rare events present an increase in these two parameters in both areas (Figures $4 \mathrm{c}$ and $5 \mathrm{c}$ ). Total rainfall attributed to rare events increased, while it is reduced for all other types in both areas (Figures $4 d$ and $5 d$ ). Frequencies for normal and rare events 
(heavy and very heavy) increased (decreased), confirming the changes observed in the previous parameters for both areas (Figures $4 \mathrm{e}$ and $5 \mathrm{e}$ ). Regarding the contribution of each type of event to the total rainfall, reductions are observed for all types of events except the normal ones in the Amazon region; however in the Northeast region an increase was observed not only for normal events but also for heavy events (Figures $4 f$ and $5 f$ ).

When Figures $4 d$ and $5 d$ are compared to $4 f$ and $5 f$, it is clear that the contribution of events to the total rainfall will be reduced independently of the type of event, because the total rainfall in both areas will be reduced by at least $30 \%$ in the future (in the Northeast region, this reduction could reach up to $40 \%)$. Moreover, all the changes observed in the different types of extreme events are the result of a redistribution of the remaining rainfall, which will have a major proportion attributed to rare events (higher than the values attributed to it in the present climate, as we can see from Figures $4 c$ and $5 c$ - increase in accumulated rare rainfall events for both regions).

\section{CONCLUSIONS}

Summarizing, the results showed that the rare events will increase in intensity and frequency in the Amazon and Northeast Brazilian regions by the end of the 21st century. The performed analysis summing all the grid points in these two regions also confirmed these findings. The results indicate that such events will account for a major amount of rainfall during the austral summer in the 2089-2099 decade, even with the reductions in the total rainfall in both areas, which suggests redistribution between the types of extreme. However, rare events will not be the top rainfall contributor, since heavy and very heavy events are the most frequent ones and responsible for the largest amounts of rainfall in these areas.

We bring to attention that more frequent extreme events will imply a higher probability of floods, especially in the Amazon basin. Of course, it not only depends on the rainfall availability but also on factors such as land use and land cover, geomorphology, social characteristics, etc. Consequently, it is necessary that local governments be prepared to assist the population occupying at-risk and vulnerable areas. In the Northeast region, the results indicate a reduction in the rainfall at the beginning of the rainy season, since the DJF trimester is no the peak of the rainy season in the area. The efforts towards the mitigation and adaption to the drought events need to continue in order to reduce the future impacts. Adaptation measures can be helpful and diminish losses (of any kind), although they may not be able to prevent them. The kind of analysis performed here joins other efforts that have been made by the scientific community to provide climate data projection, so that stakeholders can be better prepared regarding climate change issues, and also to encourage worldwide awareness regarding the effects of global warming. The extreme precipitation events still demand further analysis in order to a better understanding the behavior of climate change and the possible changes it implies.

\section{REFERENCES}


BELLPRAT, LOTT, F. C.; GULIZIA, C.; PARKER, H. R.; PAMPUCH, L. A.; PINTO, I.; CIAVARELLA, A.; STOTT, P. Unusual past dry and wet rainy seasons over Southern Africa and South America from a climate perspective. Weather and Climate Extremes, v. 9, p. 36-46, 2015.

BLACK, T. L. The New NMC Mesoscale ETA Model: Description and Forecast Examples. Weather and Forecasting, n. 9, p. 265-278, 1994.

BLÁZQUEZ, J.; NUÑEZ, M. N.; KUSUNOKI, S. Climate Projections and Uncertainties over South America from MRI/JMA Global Model Experiments. Atmospheric and Climate Sciences, v. 2, n. 4, p. 381-400, 2012.

BRITO, A. L.; VEIGA, J. A. P.; YOSHIDA, M. C. Extreme Rainfall Events over the Amazon Basin Produce Significant Quantities of Rain Relative to the Rainfall Climatology. Atmospheric and Climate Sciences, v. 4, n.2, p. 179-191, 2014.

CHADWICK, R.; GOOD, P.; MARTIN, D.; ROWELL, D. P. Large rainfall changes consistently projected over substantial areas of tropical land. Nature Climate Change, v. 6, p. 177-181, 2015.

CHEN, H.; SUN, J.; CHEN, X. Projection and uncertainty analysis of global precipitation-related extremes using CMIP5 models. International Journal of Climatology, v. 34, n. 8, p. 2730-2748, 2014.

CHOU, S. C.; MARENGO, J. A.; LYRA, A. A.; SUEIRO, G.; PESQUERO, J. F.; ALVES, L. M.; KAY, G. ; BETTS, R.; CHAGAS, D. J.; GOMES, J. L.; BUSTAMANTE, J. F.; TAVARES P. Downscaling of South America present climate driven by 4member HadCM3 runs. Climate Dynamics, v. 38, n. 3: p. 635-653, 2012.

CHOU, S. C.; LYRA, A.; MOURÃO, C.; DERECZYNSKI, C.; GOMES, J.; BUSTAMANTE, J.; TAVARES, P.; SILVA, A.; PILOTTO, I.; RODRIGUES, D.; CAMPOS, D.; CHAGAS, D.; SUEIRO, G.; SIQUEIRA, G.; MARENGO, J. Assessment of Climate Change over South America under RCP 4.5 and 8.5 Downscaling Scenarios. American Journal of Climate Change, v. 3, n. 5, p 512525, 2014.

COELHO, C. A.; CARDOSO, D. H.; FIRPO, M. A. Precipitation diagnostics of an exceptionally dry event in São Paulo, Brazil. Theoretical and Applied Climatology, v. 125, n. 3-4, p. 769-784, 2016.

COELHO, C. A.; DE OlIVEIRA, C. P.; AMBRIZZI, T.; REBOITA, M. S.; CARPENEDO, C. B.; CAMPOS, J. L. P. S.; TOMAZIELLO, A. C. N.; PAMPUCH, L. A.; CUSTODIO, M. DE S.; DUTRA, L. M. M.; DA ROCHA, R. P.; REHBEIN, A. The 2014 southeast Brazil austral summer drought: regional scale mechanisms and teleconnections. Climate Dynamics, v. 46, n. 11-12, p. 3737-3752, 2016.

COLLINS, M.; TETT, S. F. B.; COOPER, C. The internal climate variability of HadCM3, a version of the Hadley Centre coupled model without flux adjustments. Climate Dynamics, v. 17, n. 1, p. 61-81, 2001.

COLLINS, W. J.; BELLOUIN, N.; DOUTRIAUX-BOUCHER, M.; GEDNEY, N.; HALLORAN, P.; HINTON, T.; HUGHES, J.; JONES, C. D.; JOSHI, M.; LIDDICOAT, S.; MARTIN, G.; O'CONNOR, F.; RAE, J.; SENIOR, C.; SITCH, S.; TOTTERDELL, I.; WILTSHIRE, A.; WOODWARD, S. Development and evaluation of an Earth- 
System model - HadGEM2, Geoscientific Model Development, v.4, p. 10511075, 2011.

DE MORAES DRUMOND, A. R.; AMBRIZZI, T. The role of SST on the South American atmospheric circulation during January, February and March 2001. Climate Dynamics, v. 24, n. 7-8, p. 781-791, 2005.

DUARTE, F. L. TRANSPOSIÇÃO DO RIO SÃO FRANCISCO-ANÁLISE POLÍTICA, ECONÔMICA E AMBIENTAL. World Citizen Magazine, v. 2, n. 1, 2014.

ESPINOZA, J. C.; RONCHAIL, J.; FRAPPART, F.; LAVADO, W.; SANTINI, W.; GUYOT, J. L. The major floods in the Amazonas River 1 and tributaries (Western Amazon basin) during the 1970 - 2012 period: A focus on the 2012 flood. Journal of Hydrometeorology, v. 14, n. 13, p. 1000-1008, 2013.

FRICH, P.; ALEXANDER, L. V.; DELLA-MARTA, P.; GLEASON, B.; HAYLOCK, M.; KLEIN TANK, A. M. G.; PETERSON, T. Observed coherent changes in climatic extremes during the second half of the twentieth century. Climate Research $v$. 19, n. 3: p. 193-212, 2002.

GAO X., PAL J. S., GIORGI F. Projected changes in mean and extreme precipitation over the Mediterranean region from a high resolution double nested RCM simulation. Geophysical Research Letters, v. 33, n. 3, L03706, 2006.

GLOOR, M.; W. BRIENEN R. J.; GALBRAITH, D.; FELDPAUSCH, T. R.; SCHÖNGART, J.; GUYOT J-L; ESPINOZA, J. C.; LLOYD, J.; PHILLIPS, O. L. Intensification of the Amazon hydrological cycle over the last two decades. Geophysical Research Letters, v. 40, n. 9, p. 1729-1733, 2013.

GORDON, C.; COOPER, C.; SENIOR, C. A.; BANKS, H.; GREGORY,J.M.; JOHNS, T.C., MITCHELL, J.F.B; WOOD, R.A. The simulation of SST, sea ice extents and ocean heat transports in a version of the Hadley Centre coupled model without flux adjustments. Climate dynamics, v. 16, n. 2, p. 147-168, 2000.

GUIMBERTEAU, M.; RONCHAIL, J.; ESPINOZA, J. C.; LENGAIGNE, M.; SULTAN, M.; POLCHER, J.; DRAPEAU, G.; GUYOT, J-L; DUCHARNE, A.; CIAIS, P. Future changes in precipitation and impact on extreme streamflow over the Amazonian sub-basin. Environmental Research Letters, v. 8, n. 1, 014035, 13pp, 2013.

HASTENRATH, S. Exploring the climate problems of Brazil's Nordeste: a review. Climatic Change, v. 112, n. 2, p. 243-251, 2012.

KLEIN TANK A. M.G.; ZWIERS F.W.; ZHANG, X. 2011. Guidelines on Analysis of extremes in a changing climate in support of informed decisions for adaptation. World Meteorological Organization (WMO). Climate Data and Monitoring WCDMP: Switzerland, v. 75, 2009.

MARENGO, J. A.; JONES, R.; ALVES, L. M.; VALVERDE, M. C. Future change of temperature and precipitation extremes in South America as derived from the PRECIS regional climate modeling system. International Journal of Climatology, v. 29, n. 15, p. 2241-2255, 2009.

MARENGO, J. A.; CHOU, S. C.; KAY, G.; ALVES, L. M.; PESQUERO, J. F.; SOARES, W. R.; SANTOS, D. C.; LYRA, A. A.; SUEIRO, G.; BETTS, R.; CHAGAS, D. J.; GOMES, J. L.; BUSTAMANTE, J. F.; TAVARES P. Development of regional future climate change scenarios in South America using the Eta CPTEC/HadCM3 climate change projections: climatology and regional analyses for the Amazon, 
São Francisco and the Paraná River basins. Climate Dynamics, v. 38, n. 9, p. 1829-1848, 2012.

MARENGO, J. A.; ALVES, L. M.; SOARES, W. R.; RODRIGUEZ, D. A.; CAMARGO, H., RIVEROS, M. P.; PABLÓ, A. D. Two Contrasting Severe Seasonal Extremes in Tropical South America in 2012: Flood in Amazonia and Drought in Northeast Brazil. Journal of Climate, v. 26, n. 22, p. 9137-9154, 2013a.

MARENGO, J. A.; BORMA, L. S.; RODRIGUEZ, D. A.; PINHO, P.; SOARES, W. R.; ALVES, L. M. Recent Extremes of Drought and Flooding in Amazonia: Vulnerabilities and Human Adaptation. American Journal of Climate Change, v. 2, n. 2, p. 87-96, 2013b.

MARENGO, J. A.; BERNASCONI, M. Regional differences in aridity/drought conditions over Northeast Brazil: present state and future projections. Climatic Change, v. 129, n. 1-2, p. 103-115, 2015.

MARENGO, J. A.; ALVES, L. M. Crise hídrica em São Paulo em 2014: seca e desmatamento. Geousp - Espaço e Tempo (Online), v. 19, n. 3, p. 485-494, 2016.

MARENGO, J. A.; TORRES, R. R.; ALVES, L. M. Drought in Northeast Brazilpast, present, and future. Theoretical and Applied Climatology, p. 1-12, 2016.

MENDES, L. A; DE BARROS, M. T. L.; ZAMBON, R. C.; YEH, W. W-G. Trade-off analysis among multiple water uses in a hydropower system: case of São Francisco River basin, Brazil. Journal of Water Resources Planning and Management, v. 141, n. 10, p. 04015014, 2015.

MARTIN, G. M. ; BELLOUIN, N.; COLLINS, W. J.; CULVERWELL, I. D.; HALLORAN, P. R.; HARDIMAN, S. C.; HINTON, T. J.; JONES, C. D.; MCDONALD, R. E.; MCLAREN, A. J.; O'CONNOR, F. M.; ROBERTS, M. J.; RODRIGUEZ, J. M.; WOODWARD, S.; BEST, M. J.; BROOKS, M. E.; BROWN, A. R.; BUTCHART, N.; DEARDEN, C.; DERBYSHIRE, S. H.; DHARSSI, I.; DOUTRIAUX-BOUCHER, M.; EDWARDS, J. M.; FALLOON, P. D.; GEDNEY, N.; GRAY, L. J.; HEWITT, H. T.; HOBSON, M.; HUDDLESTON, M. R.; HUGHES, J.; INESON, S.; INGRAM, W. J.; JAMES, P. M.; JOHNS, T. C.; JOHNSON, C. E.; JONES, A.; JONES, C. P.; JOSHI, M. M.; KEEN, A. B.; LIDDICOAT, S.; LOCK, A. P.; MAIDENS, A. V.; MANNERS, J. C.; MILTON, S. F.; RAE, J. G. L.; RIDLEY, J. K.; SELLAR, A.; SENIOR, C. A.; TOTTERDELL, I. J.; VERHOEF, A.; VIDALE, P. L.; WILTSHIRE, A. The HadGEM2 family of Met Office Unified Model climate configurations, Geoscientific Model Development, v. 4, p. 723-757, 2011.

MESINGER, F.; JANJIC, Z.; NICKOVIC, S.; GAVRILOV, D.; DEAVEN, D. G. The step-mountain coordinates: Model description and performance for cases of Alpine Lee Cyclogenesis and for a Case of an Appalachian Redevelopment. Monthly Weather Review, v. 116, n. 6, p. 1493-1518, 1988.

NAKICENOVIC, N.; SWART, R. (Eds.). Special Report on Emissions Scenarios. Intergovernmental Panel on Climate Change. Cambridge University Press: United Kingdom, p. 570, 2000.

NOBRE, C. A.; MARENGO, J. A.; SELUCHI,, M. E.; CUARTAS, L. A.; ALVES, L. M. Some Characteristics and Impacts of the Drought and Water Crisis in Southeastern Brazil during 2014 and 2015. v. 8, n. 2, p. 252-262, 2016 
SATYAMURTY, P.; DE CASTRO, A.; TOTA, J.; GULARTE, L. E. S.; MANZI, A.O. Rainfall trends in the Brazilian Amazon Basin in the past eight decades. Theoretical Applied Climatology, v. 99, n. 1, p. 139-148, 2010.

SATYAMURTY, P.; COSTA, C. P. W.; MANZI, A. O.; CANDIDO, L. A. A quick look at the 2012 record flood in the Amazon Basin. Geophysical Research Letters, v. 40, n. 7: 1396-1401, 2013.

SILVA, V. B. S.; KOUSKY, V. E.; SHI, W.; HIGGINS, R. W. An Improved Gridded Historical Daily Precipitation Analysis for Brazil. Journal of Hydrometeorology, $v$. 8, n. 4, p. 847-861, 2007.

SORRENSSON, A. A.; MENÉNDEZ, C. G; RUSCICA, R.; ALEXANDER, P.; SAMUELSSON, P.; WILLÉN, U. Projected precipitation changes in South America: a dynamical downscaling within CLARIS. Meteorologische Zeitschrift, v. 19, n. 4, p. 347-355, 2010.

TOMPKINS, E. L.; LEMOS, M. C.; BOYD, E. A less disastrous disaster: Managing response to climate-driven hazards in the Cayman Islands and NE Brazil. Global Environmental Change, v. 18, n.4, p. 736-745, 2009.

VALVERDE, M. C.; MARENGO, J. A. Extreme Rainfall Indices in the Hydrographic Basins of Brazil. Open Journal of Modern Hydrology, v. 4, n. 1, p. 10-26, 2014. 


\section{LIST OF FIGURES}
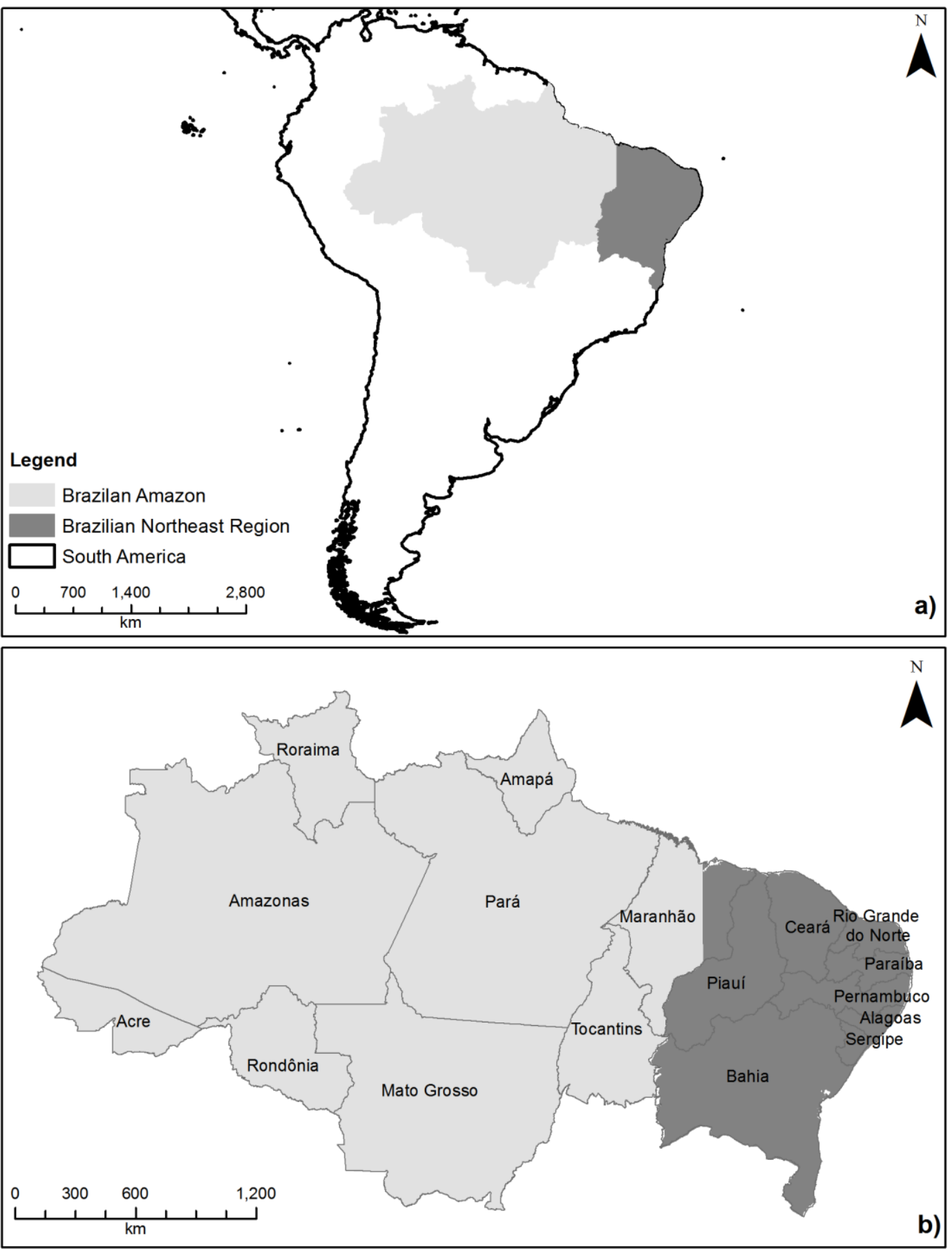

Figure 1 - Brazilian Amazon region, as indicated by light gray shaded and Northeast region, as limited by the dark gray shaded. 

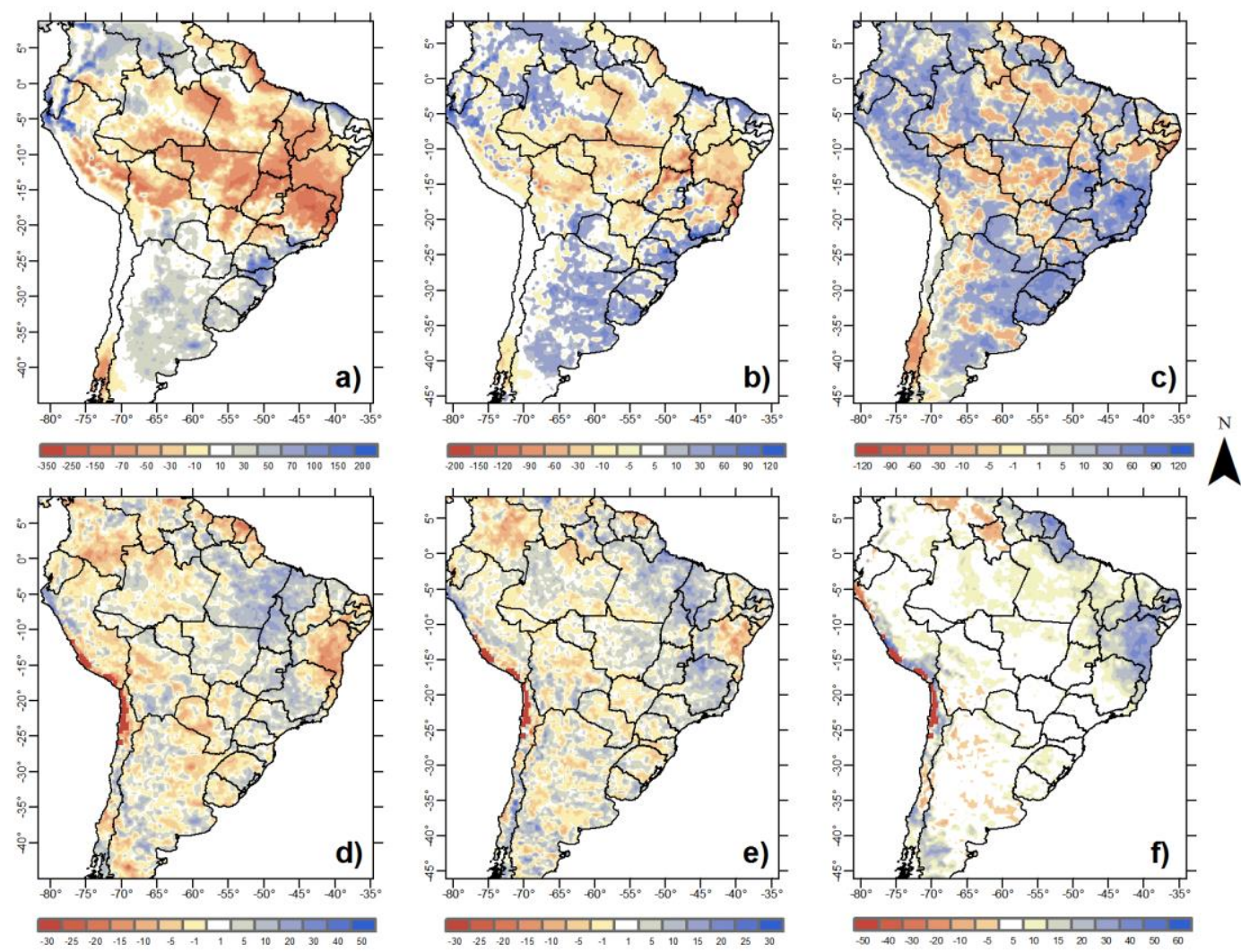

Figure 2 - Bias between the accumulated rainfall for heavy, very heavy and rare events obtained from Eta model simulations and CPC dataset both for the DJF trimester for the 1980-1990 decade.
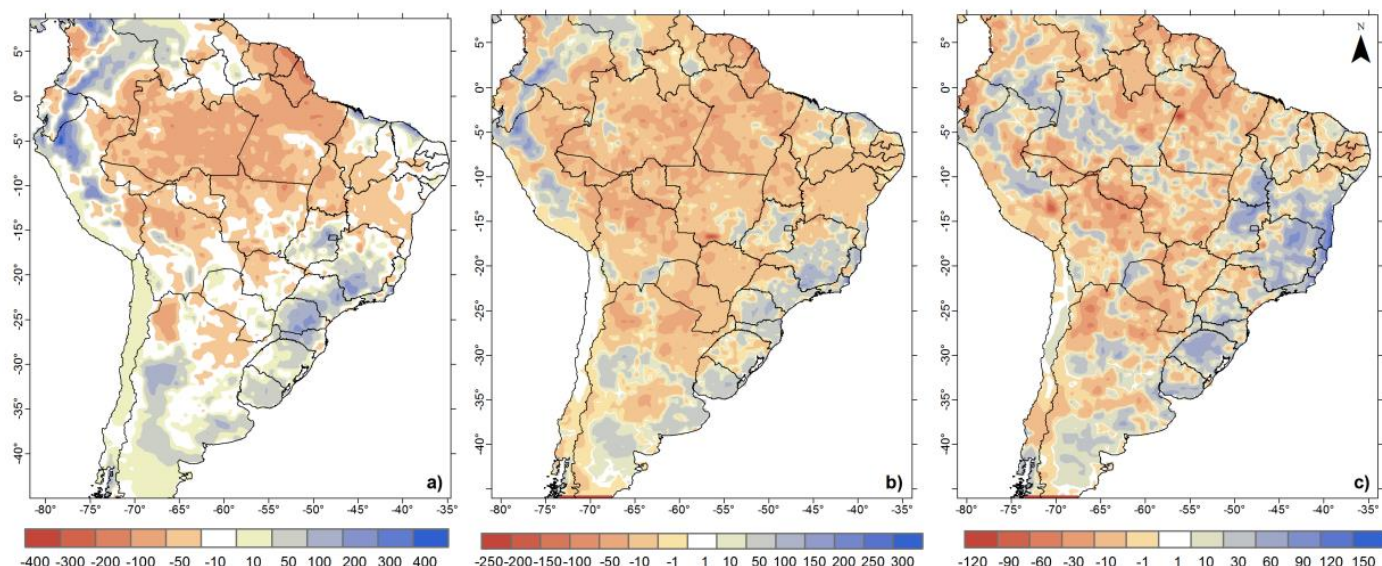

Figure 3 - Bias between the accumulated rainfall average for heavy (a), very heavy (b) and rare events (c) obtained from Eta model simulations for 2089-2099 and 1980-1990 for the DJF trimester. Bias between the rainfall contributions for each kind of extreme event to the total precipitation accumulated in the domain: heavy events (d), very heavy events (e) and rare events (f). 

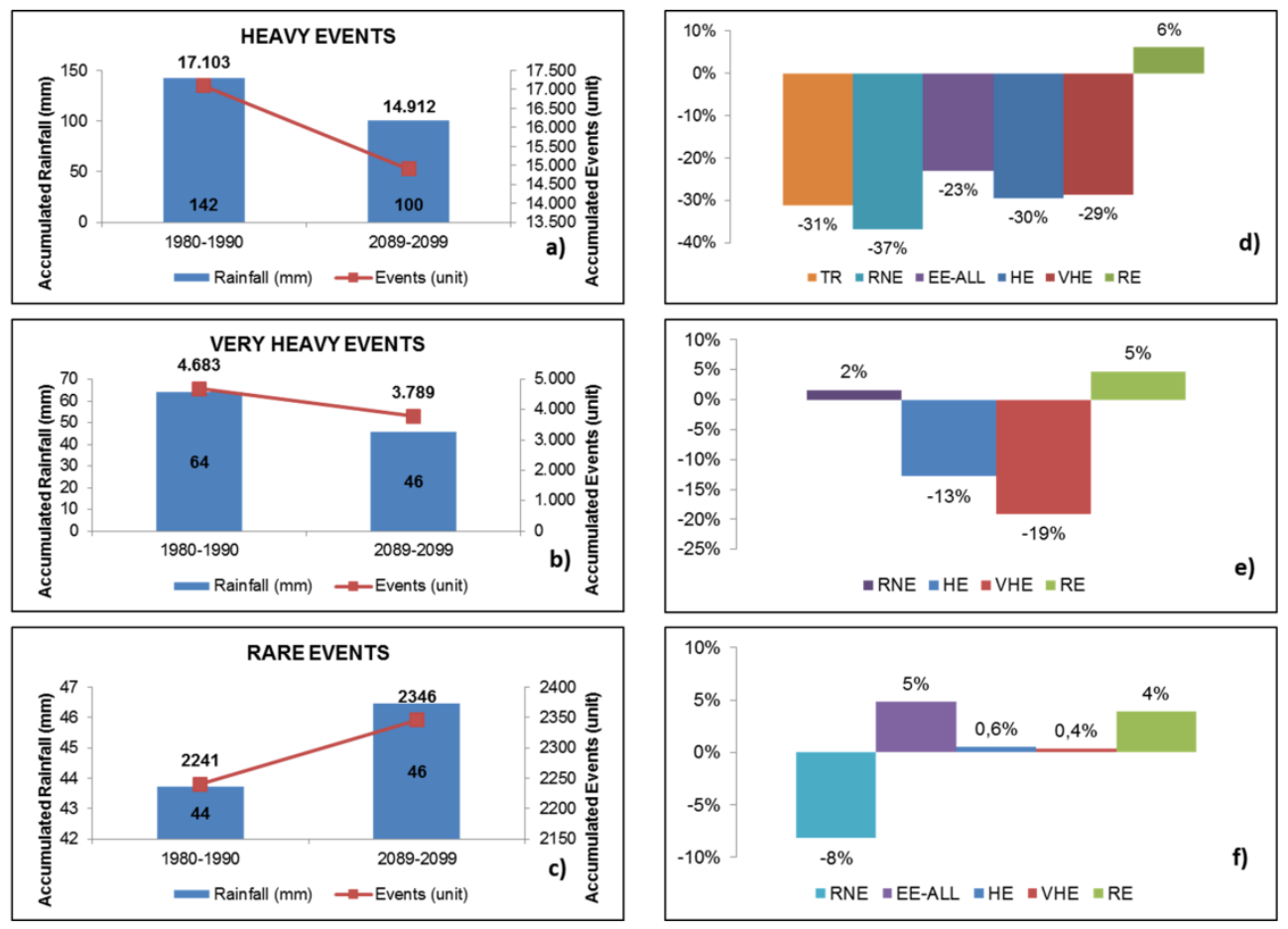

Figure 4 - (a) Mean accumulated rainfall (blue bars) and the mean number of grid points where heavy rainfall were detected (red lines) over the Amazon region for time-slices of 1980-1990 and 2089-2099. (b) same as in (a), however for very heavy events. (c) same as in (a), however for rare events. The numbers over blue bars in each panel indicate the number of grid points where a specific kind of extreme event occurred for both timeslices periods. The numbers in the center/bottom of the bars indicates the mean accumulated rainfall for each type of extreme event. This figure still brings information of bias in percentage (the difference between 2089-2090 and 1980-1990) for total rainfall accumulated in each type of event (d), accumulated events or frequency (e), and the contribution of each type of rainfall event to the total rainfall precipitated over the Amazon region. In panels $d$, e and $f, T R, R N E, E E-A L L, H E, V H E$ and $R E$, respectively, denotes for Total Rainfall, Rainfall from Normal Events, Extreme Events - ALL (it includes all the three type of extreme events), Heavy Events, Very Heavy Events and Rare Events. 

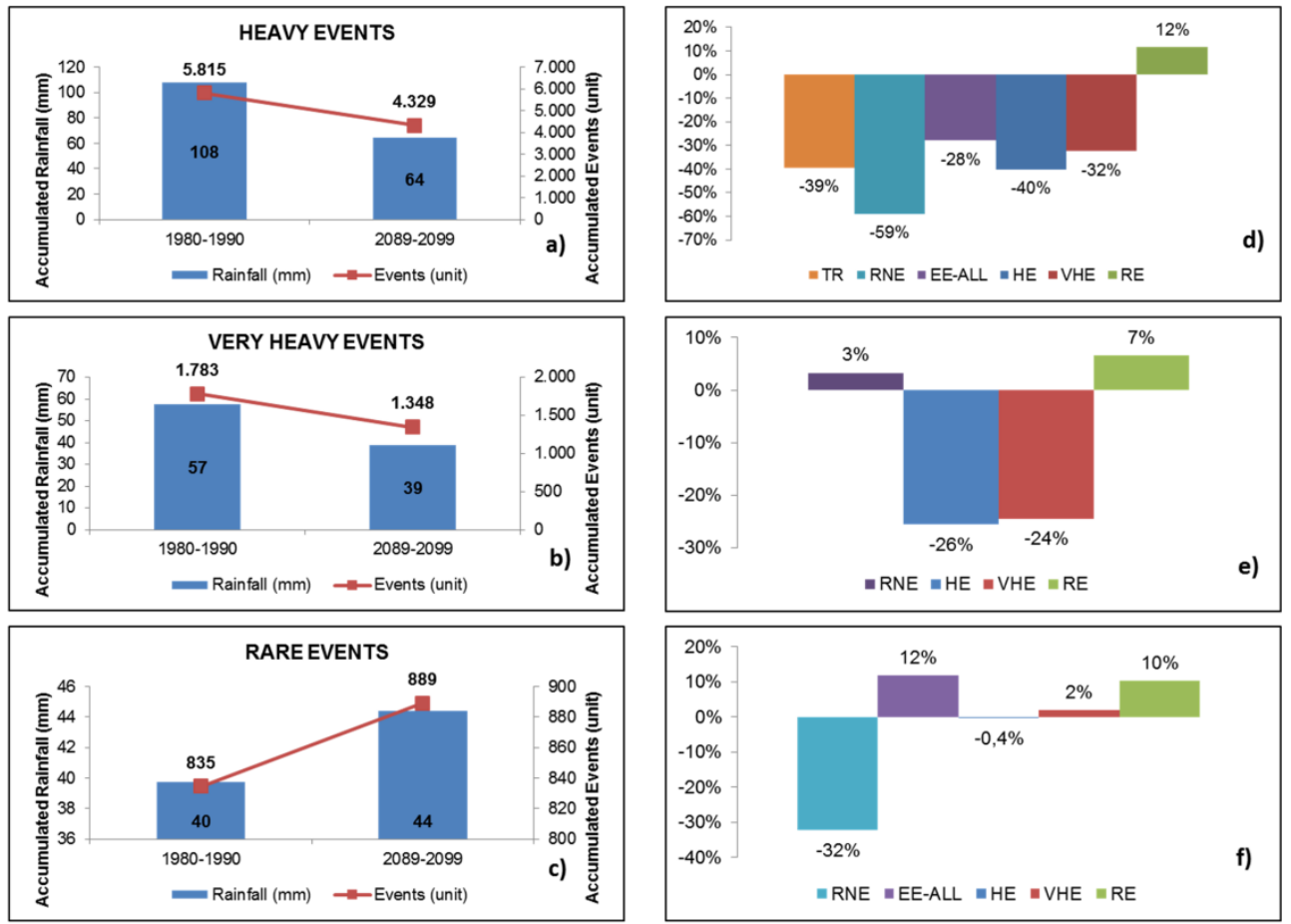

Figure 5 - Same as Figure 4, however to the Northeast region.

\section{LIST OF TABLES}

Table 1 - Resumed tendencies for the measured parameters. Ave = average rainfall (Fig $4 a, b, c ; 5 a, b, c) ;$ Attr = attributed rainfall (Fig 4d; 5d); Freq-Ave = average frequency (Fig 4a, b, c; 5a, b, c); Freq-Acc = accumulated frequency (Fig 4e; 5e); Cont = contribution to the total rainfall (Fig $4 f ; 5 f$ ).

\begin{tabular}{|c|c|c|c|c|c|c|c|c|c|c|}
\hline & \multicolumn{5}{|c|}{ Amazon } & \multicolumn{5}{|c|}{ Northeast } \\
\hline & \multirow{2}{*}{ Ave } & \multirow{2}{*}{ Attr } & \multicolumn{2}{|c|}{ Freq } & \multirow{2}{*}{ Cont } & \multirow{2}{*}{ Ave } & \multirow{2}{*}{ Attr } & \multicolumn{2}{|c|}{ Freq } & \multirow{2}{*}{ Cont } \\
\hline & & & Ave & Acc & & & & Ave & Acc & \\
\hline Total Rainfall & - & $\downarrow$ & - & - & - & - & $\downarrow$ & - & - & - \\
\hline Normal Rainfall & - & $\downarrow$ & - & $\downarrow$ & $\uparrow$ & & $\downarrow$ & - & $\downarrow$ & $\uparrow$ \\
\hline Heavy & $\downarrow$ & $\downarrow$ & $\downarrow$ & $\downarrow$ & $\uparrow$ & $\downarrow$ & $\downarrow$ & $\downarrow$ & $\downarrow$ & $\downarrow$ \\
\hline Very Heavy & $\downarrow$ & $\downarrow$ & $\downarrow$ & $\downarrow$ & $\uparrow$ & $\downarrow$ & $\downarrow$ & $\downarrow$ & $\downarrow$ & $\uparrow$ \\
\hline Rare & $\uparrow$ & $\uparrow$ & $\uparrow$ & $\uparrow$ & $\uparrow$ & $\uparrow$ & $\uparrow$ & $\uparrow$ & $\uparrow$ & $\uparrow$ \\
\hline
\end{tabular}

